\title{
Nutritional Properties of Larval Epidermis and Meat of the Edible Insect Clanis bilineata tsingtauica (Lepidoptera: Sphingidae)
}

\author{
Ying Su ${ }^{1,+}$, Ming-Xing Lu ${ }^{1,+}{ }^{+}$Li-Quan Jing ${ }^{2}$, Lei Qian ${ }^{3}$, Ming Zhao ${ }^{1}$, Yu-Zhou Du ${ }^{1,4, *}$ and Huai-Jian Liao ${ }^{3, *}$ \\ 1 College of Horticulture and Plant Protection \& Institute of Applied Entomology, Yangzhou University, \\ Yangzhou 225009, China; wulisuying@163.com (Y.S.); lumx@yzu.edu.cn (M.-X.L.); \\ zhaoming@yzu.edu.cn (M.Z.) \\ 2 Jiangsu Key Laboratory of Crop Genetics and Physiology/Co-Innovation Center for Modern Production \\ Technology of Grain Crops, Yangzhou University, Yangzhou 225009, China; lqjing@yzu.edu.cn \\ 3 Institute of Leisure Agriculture, Jiangsu Academy of Agricultural Sciences, Nanjing 210014, China; \\ qianlei14930@sina.cn \\ 4 Joint International Research Laboratory of Agriculture and Agri-Product Safety, Yangzhou University, \\ Yangzhou 225009, China \\ * Correspondence: yzdu@yzu.edu.cn (Y.-Z.D.); lhj@jaas.ac.cn (H.-J.L.) \\ + Both authors contributed equally to this work.
}

\section{check for} updates

Citation: Su, Y.; Lu, M.-X.; Jing, L.-Q.; Qian, L.; Zhao, M.; Du, Y.-Z.; Liao, H.-J. Nutritional Properties of Larval Epidermis and Meat of the Edible Insect Clanis bilineata tsingtauica (Lepidoptera: Sphingidae). Foods 2021, 10, 2895. https://doi.org/ $10.3390 /$ foods 10122895

Academic Editors: Victor

Benno Meyer-Rochow and Chuleui Jung

Received: 24 October 2021

Accepted: 17 November 2021

Published: 23 November 2021

Publisher's Note: MDPI stays neutral with regard to jurisdictional claims in published maps and institutional affiliations.

Copyright: (c) 2021 by the authors. Licensee MDPI, Basel, Switzerland. This article is an open access article distributed under the terms and conditions of the Creative Commons Attribution (CC BY) license (https:// creativecommons.org/licenses/by/ $4.0 /)$.
Abstract: Insects represent a sustainable, protein-rich food source widely consumed in Asia, Africa, and South America. Eating Clanis bilineata tsingtauica Mell is common in the eastern part of China. A comparative characterization of nutrients in the meat and epidermis of $C$. bilineata tsingtauica was performed in this study. The results showed this insect to be high in nutrients, particularly in the epidermis where protein total was $71.82 \%$. Sixteen different amino acids were quantified in C. bilineata tsingtauica, and the ratio of essential to nonessential amino acids in the epidermis and meat was $68.14 \%$ and $59.27 \%$, respectively. The amino acid composition of C. bilineata tsingtauica is balanced, representing a high-quality protein source. Eight minerals were quantified in C. bilineata tsingtauica, including four macro and four trace elements. Fe in the epidermis and $\mathrm{Zn}$ in the meat were abundant at 163.82 and $299.31 \mu \mathrm{g} / \mathrm{g}$ DW, respectively. The presence of phytic acid impacted the absorption of mineral elements in food. We also detected phytic acid in C. bilineata tsingtauica. The molar ratio of phytic acid to zinc (PA/Zn) in C. bilineata tsingtauica was very low (3.28) compared to Glycine max and Cryptotympana atrata, which indicated that mineral utilization was high. In conclusion, this study confirms that $C$. bilineata tsingtauica is a highly nutritious food source for human consumption, and the results provide a basis for further consumption and industrialization of this edible insect.

Keywords: Clanis bilineata tsingtauica Mell; edible insects; nutritional composition; phytic acid

\section{Introduction}

As the world population continues to increase, food shortage has become a serious global problem [1]. The possibility of using edible insects as food and feed was suggested in 1975 as a route to easing global food shortages [2,3] and has also been addressed by the Food and Agricultural Organization (FAO) [4,5]. Although insects are the largest and most diverse group of organisms on Earth, their implementation as a food source has not been fully utilized [6,7]. Over one million species of named insects are estimated to exist worldwide, and approximately 1900-2000 species are edible [8-10]. Humans primarily consume arthropods from one of the following five orders: Isoptera, Orthoptera, Coleoptera, Hymenoptera, and Lepidoptera [11-13]. Numerous studies have shown that these insects are of high nutritional value and contain considerable amounts of protein ( $20 \%$ to $76 \%$ of dry matter), amino acids, vitamins, and minerals [10,14-20]. Nutritional 
values are highly variable, however, because of the wide range of edible species and the variation in developmental stages and feeding substrates [3,17,21-23].

Clanis bilineata tsingtauica Mell, 1922, (Insecta: Lepidoptera: Sphingidae) is an important pest of Glycine max (Linn.) Merr. The history of C. bilineata tsingtauica as a food source dates back to the Chinese Qing Dynasty about two hundred years ago [24-26]. The consumption of the fifth instar larvae of $C$. bilineata tsingtauica is common in many regions of China, especially in the Jiangsu, Shandong, and Henan provinces [27], and Lianyungang (Jiangsu province) is a major production center. The production of C. bilineata tsingtauica in G. max amounted to approximately $3 \times 10^{4} \mathrm{t} /$ year, with an output value of nearly RMB 4.5 billion. Since the annual demand for larvae is about $10 \times 10^{4} \mathrm{t} /$ year, production has failed to satisfy consumption needs [28]. Recently, farmers in Jiangsu, Shandong, and Henan have begun growing G. max as a C. bilineata tsingtauica food source to meet consumer demand.

Many consumers believe that $C$. bilineata tsingtauica is rich in nutrients, primarily because it feeds on nutrient-dense G. max leaves. Tian et al. reported that the crude protein content of whole larvae was $65.5 \%$, essential amino acids accounted for $52.84 \%$ of total amino acids, and the content of unsaturated fatty acids was as high as $64.17 \%$ [29]. It is important to mention that different regions of China exhibit different ways of preparing and eating C. bilineata tsingtauica. For example, the processing method in Lianyungang involves removing the larval head, squeezing the body with a round wooden stick to retain the internal meat, discarding the external epidermis, and then processing the remaining body parts into a delicious soup. However, in Xuzhou (Jiangsu Province), the intact larvae with skin are chopped and fried for consumption, whereas the larvae are consumed after grilling in Shandong [27]. The variation in preparation methods indicates that a comprehensive analysis of $C$. bilineata tsingtauica is warranted.

In humans, the scarcity of mineral elements such as iron and zinc has been a difficult problem to solve [30,31]. The bioavailability of minerals in plants and plant products is inhibited by phytic acid [32-34], a derivative of inositol with six phosphate groups [35,36]. Phytic acid (PA) negatively impacts the absorption of zinc and iron in compound diets [37-40]; however, there are relatively few studies on the presence of PA in edible insects that feed on plants [41,42]. In this study, we focused on the preparation of $C$. bilineata tsingtauica using protocols typical in Lianyungang. Changes in protein and amino acid contents in the meat and epidermis of $C$. bilineata tsingtauica were determined, along with analysis of minerals and phytic acid. At the same time, compared with G. max and Cryptotympana atrata, (recorded in the Pharmacopoeia of the People's Republic of China and the Taiwan Herbal Pharmacopoeia to have medicinal value), the results of this study provide a scientific basis and reference for the nutritional value, processing methods, and further industrialization of $C$. bilineata tsingtauica.

\section{Materials and Methods}

\subsection{Collection and Preparation of Materials}

The fifth instar larvae of C. bilineata tsingtauica reared on G. max leaves were obtained from the Dongming Yellow River Beach Ecological Agriculture Co. Ltd. in Heze, Shandong Province, China $\left(35^{\circ} 14^{\prime} \mathrm{N}, 115^{\circ} 26^{\prime} \mathrm{E}\right)$. The internal meat of the larvae was removed with round wooden sticks to separate the inner material and organs from the epidermis (skin). The meat included all insect tissues except the epidermis. Larval parts were then frozen at $-70^{\circ} \mathrm{C}$ and transferred to a drying oven (Hangzhou Lantian Instrument Co., Ltd., Zhejiang, China) at $65^{\circ} \mathrm{C}$ for $24 \mathrm{~h}$. Body parts were then macerated with a stainless steel grinder (FW-100, Zhejiang, China) fitted with a 100-mesh sieve, and stored in brown, wide-mouth bottles until needed.

G. max leaves were collected from the same field as C. bilineata tsingtauica. A rice huller (OHYA-25, OHYA Corporation, Tokyo, Japan) was used to remove G. max hulls, and seeds were then pulverized into powder with a stainless steel grinder (FW-100, Zhejiang, China). For comparison, cicada, Cryptotympana atrata, was obtained from the Dongming Yellow River Beach Ecological Agriculture Co., Ltd. (Shandong, China), and the grinding and storage processes were identical to that of $C$. bilineata tsingtauica. 


\subsection{Determination of Protein Content}

Crude protein was determined by the Kjeldahl method using an automated Kjeldahl System (Buchi, Flawil, Switzerland). The protein in each sample was disintegrated by catalytic heating, which released ammonia that subsequently reacted with sulfuric acid to produce ammonium sulfate [43]. Ammonia was freed, gasified by alkaline distillation, absorbed with boric acid, and further titrated with sulfuric acid [42]. Nitrogen content was calculated as described previously, and protein content was calculated by multiplying the result by a conversion factor of $6.25[43,44]$.

The contents of albumin, globulin, glutelin, and prolamin were determined as described by Ju et al. [45]. In brief, the sample was first defatted with hexane and then subjected to protein extraction. The above protein was extracted with distilled water, $50 \mathrm{~g} / \mathrm{L} \mathrm{NaCl}, 0.02 \mathrm{~mol} / \mathrm{L} \mathrm{NaOH}$, and $700 \mathrm{~mL} / \mathrm{L}$ ethanol in sequence [46].

\subsection{Determination of Amino Acid Content}

AccQ·Tag high-performance liquid chromatography (HPLC) was used to measure amino acid content, and all HPLC analyses were performed on a Waters 2695 HPLC system (Waters Corporation, Milford, MA, USA). About $0.10 \mathrm{~g}$ of the powder sample was weighed into a $10 \mathrm{~mL}$ glass bottle; then $5.00 \mathrm{~mL}$ of $6 \mathrm{~mol} / \mathrm{L} \mathrm{HCl}$ was added and the mixture was well-shaken and sealed. After the bottle was placed in an oven at $110{ }^{\circ} \mathrm{C}$ for $24 \mathrm{~h}$, the samples were run through filters for quantification and the volume was adjusted to $50 \mathrm{~mL}$. The filtrate $(2.00 \mathrm{~mL})$ was transferred into a cuvette, and low-pressure evaporation was used to remove $\mathrm{HCl}$ in a vacuum freeze drier (Labconco Corporation, Kansas, MO, USA). The concentrate thus obtained was dissolved in $2.00 \mathrm{~mL}$ of pure water, and the solution was filtrated with a $0.45 \mu \mathrm{m}$ membrane filter. Then, $10 \mu \mathrm{L}$ of filtrate, $70 \mu \mathrm{L}$ of AccQ. Fluor buffer, and $20 \mu \mathrm{L}$ of derivatizing agent (Waters Corporation, Milford, MA, USA) were transferred successively into the derivatization tube, and the mixture was warmed at $55^{\circ} \mathrm{C}$ for $10 \mathrm{~min}$ in an oven (Hangzhou Lantian Instrument Co., Ltd., Zhejiang, China). Finally, amino acid content was determined by high-performance liquid chromatography (Waters 2695 HPLC separation unit, 2487 UV detector, Waters Co., Milford, MA, USA, and Empower management system, X\&Y Solutions, Inc., Boston, MA, USA). The AccQ.Tag reversed-phase analysis column was $3.9 \mathrm{~mm} \times 150 \mathrm{~mm}$; mobile phase A was sodium acetate $(140 \mathrm{mmol} / \mathrm{L})$-ethylamine $(17 \mathrm{mmol} / \mathrm{L}, \mathrm{pH} 4.95$, adjusted with phosphoric acid); mobile phase $\mathrm{B}$ was acetonitrile; and mobile phase $\mathrm{C}$ was pure water. Flow velocity was $1.00 \mathrm{~mL} / \mathrm{min}$; column temperature was $37^{\circ} \mathrm{C}$; $\mathrm{UV}$ detector wavelength was $248 \mathrm{~nm}$; sample volume was $10 \mu \mathrm{L}$. The standards of 17 amino acid components were provided by Waters Co. Ltd. (Milford, MA, USA), except for tryptophan (Trp) [44].

A Waters 2695 HPLC detection system was used to determine the quantity of seven essential amino acids, including threonine (Thr), valine (Val), methionine (Met), isoleucine (Ile), leucine (Leu), phenylalanine (Phe), and lysine (Lys), but not tryptophan (Trp). The content of the following nine nonessential amino acids was also determined: aspartic acid (Asp), serine (Ser), glutamic acid (Glu), glycine (Gly), alanine (Ala), arginine (Arg), proline (Pro), histidine (His) tyrosine (Tyr), and cysteine (Cys) [44].

The following equations were used for evaluating amino acids:

$$
\begin{gathered}
\text { Amino acid score }(\mathrm{AAS})=\frac{m g \text { of amino acid in test protein }}{m g \text { of amino acid in FAO model }} \\
\text { Chemical score }(\mathrm{CS})=\frac{m g \text { of amino acid in test protein }}{m g \text { of amino acid in eggs }} \\
\text { Essential amino acid index (EAAI) }=\sqrt[n]{\frac{L y s^{t}}{L y s^{s}} \times 100 \times \frac{T r p^{t}}{\operatorname{Tr} p^{s}} \times 100 \times \cdots \times \frac{T h r^{t}}{T h r^{s}} \times 100}
\end{gathered}
$$

where $n$ is the total number of essential amino acids, $t$ is the amino acid content of the sample, and $s$ is the amino acid content of the egg. 


\subsection{Determination of Mineral Content}

Inductively coupled plasma-atomic emission spectroscopy (ICP-AES, ICAP 6300, Thermo, Waltham, MA, USA) was used for rapid and precise determinations of macro and trace mineral content in the samples. Briefly, pulverized samples $(0.50 \mathrm{~g})$ were weighed and combined with ultrapure-grade $\mathrm{HNO}_{3}(5.00 \mathrm{~mL})$ and $\mathrm{H}_{2} \mathrm{O}_{2}(2.00 \mathrm{~mL})$. A microwave digester (CEM MARS 5, Matthews, NC, USA) and the easy prep microwave digestion program were used to digest the samples [47]. After complete digestion, the mixed sample was cooled at room temperature and increased to a final volume of $20 \mathrm{~mL}$ with ultrapure water. Then, macro elements $(\mathrm{Ca}, \mathrm{K}, \mathrm{Mg}$, and $\mathrm{P})$ and trace elements $(\mathrm{Cu}, \mathrm{Fe}, \mathrm{Mn}$, and $\mathrm{Zn})$ were determined using ICP-AES. The optimal instrumental conditions were maintained at $15 \mathrm{~L} / \mathrm{min}$ for the stable plasma gas flow rate. The auxiliary and the nebulizer gas flow rate were kept at 0.2 and $0.8 \mathrm{~L} / \mathrm{min}$, respectively. The sample flow rate was $1.5 \mathrm{~mL} / \mathrm{min}$, and the power was $1500 \mathrm{~W}$.

\subsection{Determination of Phytic Acid Content}

Pulverized samples $(0.25 \mathrm{~g})$ were weighed and combined with a $0.7 \% \mathrm{HCl}$ solution $(5.00 \mathrm{~mL})$. This mixture was incubated in a constant-temperature oscillator at $25^{\circ} \mathrm{C}$ and $150 \mathrm{rpm}$ for $1 \mathrm{~h}$. After centrifugation at $4000 \mathrm{rpm}$ for $15 \mathrm{~min}$ at $4{ }^{\circ} \mathrm{C}$, supernatants were collected. Supernatants $(0.60 \mathrm{~mL})$ were combined with $2.40 \mathrm{~mL}$ of deionized water and $0.50 \mathrm{~mL}$ of $\mathrm{FeCl}_{3}(0.1 \%, w / v)$; the mixture was shaken and then centrifuged at $3400 \mathrm{rpm}$ for $10 \mathrm{~min}$. The absorbance of supernatants was measured with a spectrophotometer (UV-1601 UV-VIS Spectrophotometer, Shimadzu Corporation, Tokyo, Japan) at $500 \mathrm{~nm}$, and the amount of phytic acid was calculated using a phytic acid standard curve [44].

\subsection{Statistical Analyses}

Results are shown as means \pm standard deviation (SD). Analysis of $C$. bilineata tsingtauica was compared with G. max and C. atrata. Data were stored in Microsoft Excel (2013) and analyzed with SPSS v. 16.0 statistical software.

\section{Results}

\subsection{Classification and Determination of Total Protein}

The total protein content of C. bilineata tsingtauica was higher than G. max, and more abundant in the larval epidermis $(71.82 \%)$ than in the meat (64.24\%) (Table 1). Four proteins, including albumin, globulin, glutelin, and prolamin, were identified in C. bilineata tsingtauica, and had different concentrations in the larval meat and epidermis. For example, glutelin was the predominant protein (meat, $34.35 \%$; epidermis, $34.23 \%$ ) and globulin was the least abundant (meat, $5.13 \%$; epidermis, $3.70 \%$ ). Prolamin content in the C. bilineata tsingtauica epidermis $(11.67 \%)$ was double that found in the meat $(5.27 \%)$. Interestingly, prolamin levels in the C. bilineata tsingtauica epidermis and C. atrata (11.02\%) were eight-fold greater than levels in G. max (1.28\%) (Table 1).

Table 1. The protein content (\% dry weight) in Clanis bilineata tsingtauica, Glycine max, and Cryptotympana atrata.

\begin{tabular}{ccccc}
\hline & $\begin{array}{c}\text { Clanis bilineata } \\
\text { tsingtauica } \\
\text { Meat }\end{array}$ & $\begin{array}{c}\text { Clanis bilineata } \\
\text { tsingtauica } \\
\text { Epidermis }\end{array}$ & $\begin{array}{c}\text { Glycine max } \\
\text { (CK })\end{array}$ & $\begin{array}{c}\text { Cryptotympana } \\
\text { atrata }\left(\mathbf{C K}_{\mathbf{2}}\right)\end{array}$ \\
\hline Albumin & $19.50 \pm 2.40$ & $22.25 \pm 8.56$ & $33.55 \pm 2.05$ & $12.75 \pm 4.03$ \\
Globulin & $5.27 \pm 1.20$ & $3.70 \pm 0.57$ & $4.56 \pm 0.30$ & $3.53 \pm 0.39$ \\
Glutelin & $34.35 \pm 4.43$ & $34.23 \pm 3.49$ & $8.17 \pm 0.52$ & $39.07 \pm 3.20$ \\
Prolamin & $5.13 \pm 0.98$ & $11.67 \pm 1.32$ & $1.28 \pm 0.35$ & $11.02 \pm 2.01$ \\
Total protein & $64.25 \pm 0.21$ & $71.85 \pm 3.18$ & $47.55 \pm 1.63$ & $66.35 \pm 4.74$ \\
\hline Note: Data are expressed as means + SD (standard deviation).
\end{tabular}

Note: Data are expressed as means \pm SD (standard deviation). 


\subsection{Essential and Nonessential Amino Acid Content}

Sixteen amino acids were analyzed in C. bilineata tsingtauica, including seven essential amino acids (EAA) and nine nonessential amino acids (NEAA). Trp was not measured (an alkaline hydrolysis method is needed), and Cys could not be determined due to analytical methods and not necessarily because it was absent. The total amino acid content (TAA) of the C. bilineata tsingtauica meat and epidermis was 455.62 and $710.07 \mathrm{mg} / \mathrm{g}$ DW, respectively. Both EAA and NEAA were higher in the larval epidermis than in the meat (Table 2). In the epidermis, the EAA and NEAA contents were 287.75 and $422.33 \mathrm{mg} / \mathrm{g} \mathrm{DW}$, respectively. Furthermore, the EAA/NEAA ratio (meat, 59.27\%; epidermis, $68.14 \%$ ) and EAA/TAA ratio (meat, 37.18\%; epidermis, $40.51 \%$ ) were higher in the epidermis than in the meat. Among the seven EAAs, Leu content was the highest in the C. bilineata tsingtauica meat ( $40.81 \mathrm{mg} / \mathrm{g}$ DW), Lys was highest in the epidermis $(59.05 \mathrm{mg} / \mathrm{g}$ DW), and the Met content was the lowest of the four EAAs in both the meat and epidermis. Among the nine NEAAs, the Glu content was highest in the C. bilineata tsingtauica meat $(78.40 \mathrm{mg} / \mathrm{g}$ DW) and epidermis (99.21 mg/g DW), and the Pro content was the lowest (meat, 3.60; epidermis, $3.69 \mathrm{mg} / \mathrm{g}$ DW). All 16 amino acids exhibited a higher content in the epidermis than in the C. bilineata tsingtauica meat. The TAA, EAA, and NEAA contents in the four food sources were ranked from high to low as follows: G. max, C. bilineata tsingtauica epidermis, C. atrata, and C. bilineata tsingtauica meat. The contents of Thr, Met, Ile, Leu, Lys, Glu, and Arg in the epidermis of C. bilineata tsingtauica were higher than in G. max and C. atrata; but the Phe content of G. $\max (107.26 \mathrm{mg} / \mathrm{g}$ DW) was over four-fold higher than that of the C. bilineata tsingtauica meat $(24.81 \mathrm{mg} / \mathrm{g} \mathrm{DW})$, and more than twice that of the C. bilineata tsingtauica epidermis (40.64 mg/g DW) (Table 2).

The amino acid score (AAS), chemical score (CS), and essential amino acid index (EAAI) are important indicators to further evaluate the quality of amino acids. With respect to EAAs, our results showed the AAS of Met in C. bilineata tsingtauica was the lowest (meat, 0.27; epidermis, 0.54), which defined the first limiting amino acid (Table 3). The highest AAS score was that of the aromatic amino acids (Phe $+\mathrm{Tyr}$ ) in the meat and epidermis of $C$. bilineata tsingtauica, where values were 0.72 (meat) and 1.33 (epidermis). The content of Ile, Lys, Phe + Tyr, and Thr in the epidermis of $C$. bilineata tsingtauica exceeded the amino acid content in the FAO standard, and the content of total essential amino acids was higher in the epidermis of $C$. bilineata tsingtanica compared to the FAO standard. Furthermore, the AAS and CS of essential amino acids in the epidermis of $C$. bilineata tsingtauica were higher than those in the meat (Table 3). C. bilineata tsingtauica possessed an excellent amino acid index of 87.67 in the meat and 94.91 in the epidermis (Figure 1). The overall EAAI was slightly lower for C. bilineata tsingtauica compared to G. max.

Table 2. Amino acid content in C. bilineata tsingtauica, Glycine max, and Cryptotympana atrata (mg/g DW).

\begin{tabular}{ccccc}
\hline & $\begin{array}{c}\text { Clanis bilineata } \\
\text { tsingtauica } \\
\text { Meat }\end{array}$ & $\begin{array}{c}\text { Clanis bilineata } \\
\text { tsingtauica } \\
\text { Epidermis }\end{array}$ & $\begin{array}{c}\text { Glycine max } \\
\left(\mathbf{C K}_{\mathbf{1}}\right)\end{array}$ & $\begin{array}{c}\text { Cryptotympana } \\
\text { atrata }\left(\mathbf{C K}_{\mathbf{2}} \mathbf{)}\right.\end{array}$ \\
\hline Thr * $^{*}$ & $23.35 \pm 4.34$ & $44.22 \pm 2.81$ & $42.37 \pm 5.59$ & $29.95 \pm 1.51$ \\
Val $^{*}$ & $22.85 \pm 1.00$ & $33.17 \pm 4.12$ & $37.85 \pm 4.91$ & $25.05 \pm 1.78$ \\
Met $_{\text {Ile }}^{*}$ & $9.49 \pm 1.22$ & $18.81 \pm 1.21$ & $10.40 \pm 1.09$ & $6.73 \pm 0.74$ \\
Leu $^{*}$ & $21.02 \pm 1.71$ & $40.79 \pm 2.08$ & $36.74 \pm 4.41$ & $29.73 \pm 2.76$ \\
Phe $^{*}$ & $40.81 \pm 2.55$ & $50.89 \pm 6.54$ & $41.23 \pm 6.50$ & $39.67 \pm 2.67$ \\
Lys & $24.81 \pm 3.10$ & $40.64 \pm 3.21$ & $107.26 \pm 6.93$ & $34.65 \pm 1.76$ \\
Trp & $26.91 \pm 1.82$ & $59.05 \pm 2.38$ & $48.73 \pm 14.81$ & $42.03 \pm 1.51$ \\
Asp & - & - & - & - \\
Ser & $45.49 \pm 7.47$ & $66.59 \pm 2.47$ & $69.51 \pm 7.28$ & $64.38 \pm 2.86$ \\
Glu & $24.53 \pm 4.26$ & $35.12 \pm 3.02$ & $40.15 \pm 1.53$ & $31.56 \pm 2.89$ \\
& $78.40 \pm 2.18$ & $99.21 \pm 2.04$ & $93.21 \pm 4.42$ & $97.59 \pm 1.44$ \\
\hline
\end{tabular}


Table 2. Cont.

\begin{tabular}{ccccc}
\hline & $\begin{array}{c}\text { Clanis bilineata } \\
\text { tsingtauica } \\
\text { Meat }\end{array}$ & $\begin{array}{c}\text { Clanis bilineata } \\
\text { tsingtauica } \\
\text { Epidermis }\end{array}$ & $\begin{array}{c}\text { Glycine max } \\
\left(\mathbf{C K}_{\mathbf{1}}\right)\end{array}$ & $\begin{array}{c}\text { Cryptotympana } \\
\text { atrata }\left(\mathbf{C K}_{\mathbf{2}}\right)\end{array}$ \\
\hline Gly & $28.43 \pm 1.84$ & $42.37 \pm 3.56$ & $48.97 \pm 2.99$ & $30.74 \pm 2.65$ \\
Ala & $35.52 \pm 3.28$ & $47.76 \pm 2.98$ & $52.52 \pm 4.02$ & $28.34 \pm 2.58$ \\
Tyr & $18.38 \pm 0.78$ & $39.11 \pm 3.04$ & $58.96 \pm 2.26$ & $24.50 \pm 2.69$ \\
Arg & $30.92 \pm 3.08$ & $54.82 \pm 4.94$ & $40.30 \pm 1.54$ & $48.68 \pm 0.52$ \\
Pro & $3.60 \pm 0.48$ & $3.69 \pm 0.11$ & $6.28 \pm 0.39$ & $3.79 \pm 0.45$ \\
His & $21.13 \pm 1.25$ & $33.68 \pm 2.24$ & $39.60 \pm 4.16$ & $21.29 \pm 3.14$ \\
Cys & - & - & - & - \\
EAA & $169.23 \pm 1.97$ & $287.75 \pm 15.49$ & $324.56 \pm 3.43$ & $207.72 \pm 7.87$ \\
NEAA & $286.39 \pm 20.95$ & $422.33 \pm 1.22$ & $449.48 \pm 16.70$ & $350.84 \pm 7.29$ \\
TAA & $455.62 \pm 22.92$ & $710.07 \pm 14.27$ & $774.04 \pm 20.13$ & $558.55 \pm 15.16$ \\
EAA/NEAA (\%) & $59.23 \pm 3.64$ & $68.14 \pm 3.86$ & $72.24 \pm 1.92$ & $59.20 \pm 1.01$ \\
EAA/TAA (\%) & $37.18 \pm 1.44$ & $40.51 \pm 1.37$ & $41.94 \pm 0.65$ & $37.19 \pm 0.40$ \\
\hline
\end{tabular}

Abbreviations: * essential amino acids (EAAs); -, not determined; EAA/NEAA, ratio of EAA and nonessential amino acids; EAA/TAA, ratio of EAA and total amino acids (TAA). Data are expressed as means \pm SD.

Table 3. Comparison of the amino acid score and chemical score in Clanis bilineata tsingtauica with other sources.

\begin{tabular}{ccccccccc}
\hline & \multicolumn{3}{c}{ Content (mg/g DW) } & \multicolumn{3}{c}{ AAS } & \multicolumn{2}{c}{ CS } \\
\cline { 2 - 8 } & FAO * & Eggs * & Meat & Epidermis & Meat & Epidermis & Meat & Epidermis \\
\hline Ile & 40 & 52.4 & 21.02 & 40.99 & 0.53 & 1.02 & 0.40 & 0.78 \\
Leu & 70 & 84.1 & 40.81 & 50.89 & 0.58 & 0.73 & 0.49 & 0.61 \\
Lys & 55 & 64.9 & 26.91 & 59.05 & 0.49 & 1.07 & 0.41 & 0.91 \\
Met & 35 & 62.7 & 9.49 & 18.81 & 0.27 & 0.54 & 0.15 & 0.30 \\
Phe + Tyr & 60 & 95.5 & 43.19 & 79.75 & 0.72 & 1.33 & 0.45 & 0.84 \\
Thr & 40 & 53.9 & 23.35 & 44.22 & 0.58 & 1.11 & 0.43 & 0.82 \\
Trp & 10 & 16.2 & - & - & - & - & - & - \\
Val & 50 & 57.6 & 22.85 & 33.17 & 0.46 & 0.66 & 0.40 & 0.58 \\
TAA & 360 & 487.3 & 217.94 & 362.60 & - & - & - & - \\
\hline
\end{tabular}

Note: * amino acid content as reported by Qiao et al. [48]; -, not determined. Abbreviations: AAS, amino acid score; CS, chemical score; FAO, Food and Agricultural Organization; TAA, total amino acids.

\subsection{Determination of Mineral Content}

The contents of four macro elements (calcium, potassium, magnesium, and phosphorus) and four trace elements (copper, iron, manganese, and zinc) were determined in C. bilineata tsingtauica (Table 4). Among the macro elements, Ca content was the highest in the meat $(0.57 \mathrm{mg} / \mathrm{g} \mathrm{DW})$ and epidermis $(0.73 \mathrm{mg} / \mathrm{g} \mathrm{DW})$, whereas $\mathrm{Mg}$ was the lowest (meat, 13.92; epidermis, $11.24 \mathrm{mg} / \mathrm{g} \mathrm{DW}$ ). As for trace elements in the C. bilineata tsingtauica meat, $\mathrm{Cu}$ content was the lowest $(6.79 \mu \mathrm{g} / \mathrm{g}$ DW) and $\mathrm{Zn}$ was the highest $(299.31 \mu \mathrm{g} / \mathrm{g}$ DW), whereas Mn was the lowest $(11.04 \mu \mathrm{g} / \mathrm{g}$ DW) and Fe was the highest $(163.82 \mu \mathrm{g} / \mathrm{g}$ $\mathrm{DW}$ ) in the epidermis. The $\mathrm{K}, \mathrm{Mg}, \mathrm{P}$, and $\mathrm{Zn}$ concentrations were higher in the $\mathrm{C}$. bilineata tsingtauica meat than in the epidermis; however, the $\mathrm{Ca}, \mathrm{Cu}, \mathrm{Fe}$, and $\mathrm{Mn}$ concentrations were higher in the epidermis than in the meat. Notable differences in the mineral content of C. bilineata tsingtauica and G. max included Fe in the epidermis and $\mathrm{Zn}$ content in the meat, which were about two- and six-fold higher than G. max, respectively (Table 4). 


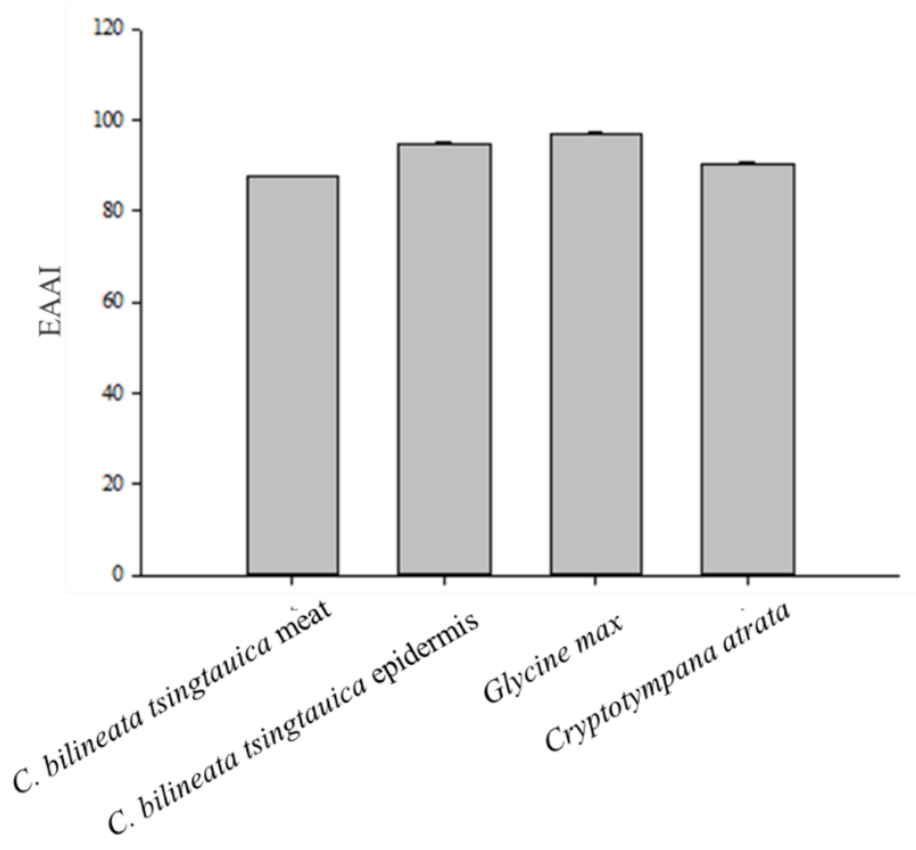

Figure 1. The essential amino acid index (EAAI) in Clanis bilineata tsingtauica, Glycine max, and Cryptotympana atrata.

Table 4. Mineral element content in Clanis bilineata tsingtauica, Glycine max, and Cryptotympana atrata (DW).

\begin{tabular}{ccccc}
\hline & $\begin{array}{c}\text { Clanis bilineata } \\
\text { tsingtauica } \\
\text { Meat }\end{array}$ & $\begin{array}{c}\text { Clanis bilineata } \\
\text { tsingtauica } \\
\text { Epidermis }\end{array}$ & $\begin{array}{c}\text { Glycine max } \\
\left(\mathbf{C K}_{\mathbf{1}}\right)\end{array}$ & $\begin{array}{c}\text { Cryptotympana } \\
\text { atrata }\left(\mathbf{C K}_{\mathbf{2}} \mathbf{)}\right.\end{array}$ \\
\hline $\mathrm{Ca}(\mathrm{mg} / \mathrm{g}) *$ & $0.57 \pm 0.12$ & $0.73 \pm 0.01$ & $0.98 \pm 0.03$ & $1.59 \pm 0.15$ \\
$\mathrm{~K}(\mathrm{mg} / \mathrm{g}) *$ & $12.53 \pm 2.08$ & $9.52 \pm 0.13$ & $13.56 \pm 1.02$ & $5.45 \pm 0.16$ \\
$\mathrm{Mg}(\mathrm{mg} / \mathrm{g}) *$ & $13.92 \pm 2.21$ & $11.24 \pm 0.48$ & $21.75 \pm 0.49$ & $12.09 \pm 1.45$ \\
$\mathrm{P}(\mathrm{mg} / \mathrm{g}) *$ & $7.91 \pm 0.44$ & $3.06 \pm 0.15$ & $5.10 \pm 0.50$ & $5.30 \pm 0.24$ \\
$\mathrm{Cu}(\mu \mathrm{g} / \mathrm{g})$ & $6.79 \pm 0.62$ & $11.48 \pm 0.29$ & $14.00 \pm 0.91$ & $33.15 \pm 0.16$ \\
$\mathrm{Fe}(\mu \mathrm{g} / \mathrm{g})$ & $63.05 \pm 7.94$ & $163.82 \pm 4.08$ & $87.88 \pm 4.19$ & $532.80 \pm 30.92$ \\
$\mathrm{Mn}(\mu \mathrm{g} / \mathrm{g})$ & $10.57 \pm 2.39$ & $11.04 \pm 0.02$ & $23.37 \pm 1.44$ & $391.98 \pm 13.51$ \\
$\mathrm{Zn}(\mu \mathrm{g} / \mathrm{g})$ & $299.31 \pm 39.69$ & $94.80 \pm 20.57$ & $44.71 \pm 3.11$ & $296.06 \pm 33.54$ \\
\hline
\end{tabular}

Note: * macro element. Data are expressed as means \pm SD.

\subsection{Phytic Acid (PA) Content and Mineral Bioavailability}

Analysis showed that PA was present in both C. bilineata tsingtauica and C. atrata, but the concentration was lower than in G. max (Figure 2). The PA content of the C. bilineata tsingtauica epidermis (16.47 mg/g DW) was higher than that of the meat (Figure 2). The $\mathrm{PA} / \mathrm{Zn}$ ratio in C. bilineata tsingtauica meat was 3.28, lower than the epidermis, G. max, and C. atrata (Figure 3). The PA/Fe ratio in C. atrata was 2.95, lower than C. bilineata tsingtauica and G. max. It is also important to note that the PA/Fe ratios in the C. bilineata tsingtauica meat and epidermis were lower than G. max at 13.13 and 8.52, respectively (Figure 3). 


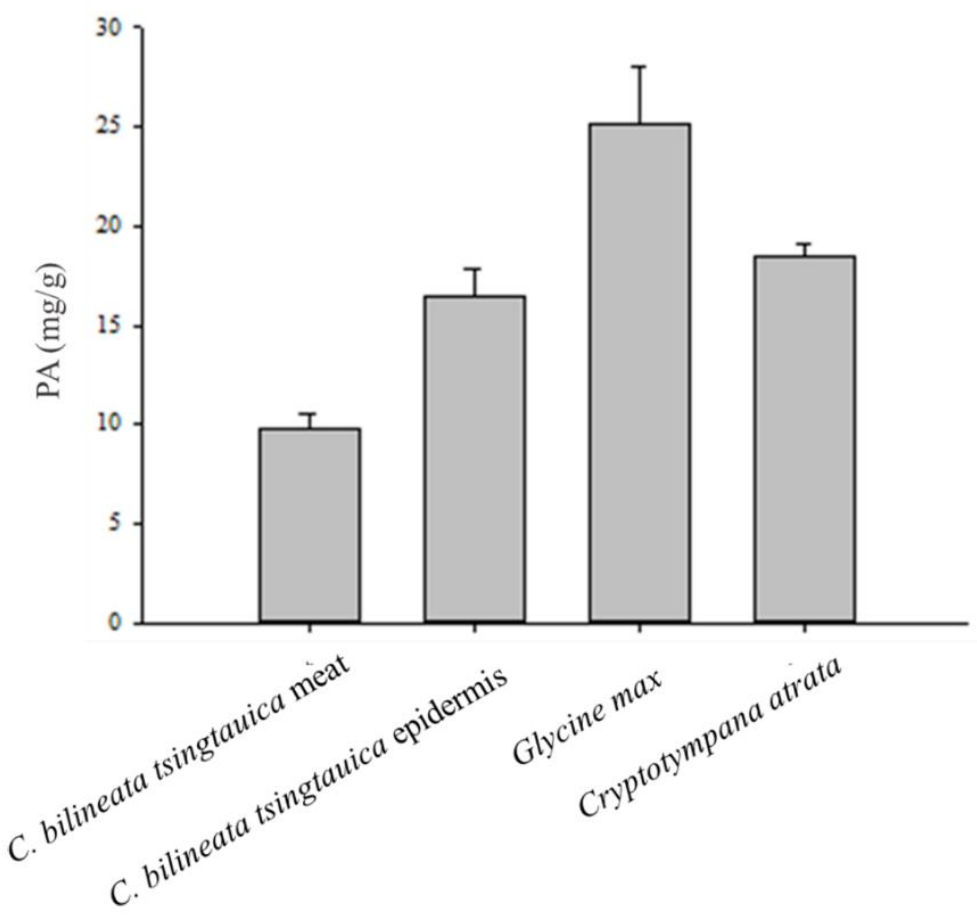

Figure 2. Phytic acid content in Clanis bilineata tsingtauica, Glycine max, and Cryptotympana atrata (DW).
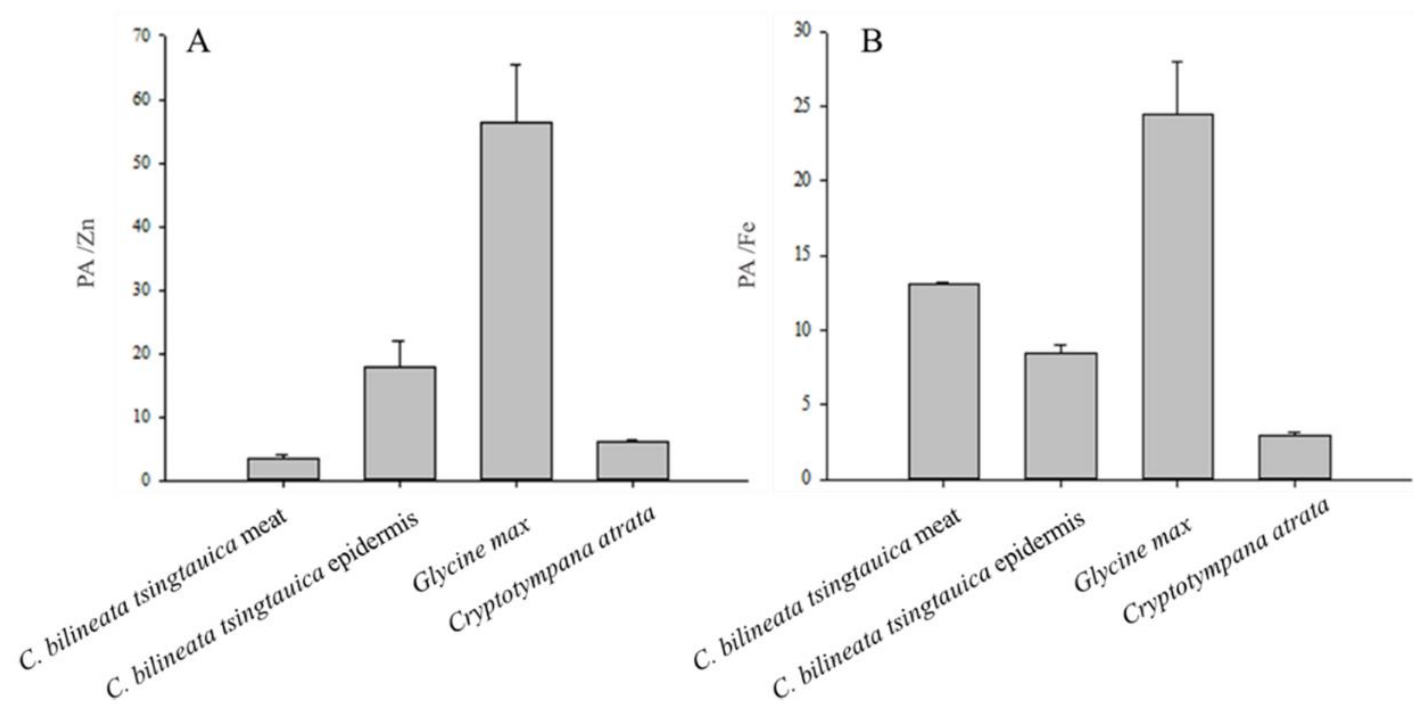

Figure 3. Bioavailability of $\mathrm{Zn}(\mathbf{A})$ and $\mathrm{Fe}(\mathbf{B})$ in Clanis bilineata tsingtauica, Glycine max, and Cryptotympana atrata.

\section{Discussion}

According to the FAO, insects are an environmentally friendly food source for the growing world population [49]. As an edible insect, C. bilineata tsingtauica has a long history in China and is loved by the Chinese people. In this study, we found that $C$. bilineata tsingtauica is rich in protein, and the glutelin content is much higher than in G. max. Edible insects generally have a rich protein content and supply energy for various physiological functions [50-54]. Although many researchers have tried to substitute edible insect protein for meat protein [55], it is important to consider the risks of food allergy following insect ingestion [56], and possible pathogens in insects, too. 
The essential amino acid composition of $C$. bilineata tsingtauica is relatively balanced and comprehensive. According to FAO standards, the ratios of EAA/NEAA and EAA/TAA in the C. bilineata tsingtauica epidermis meet the FAO/WHO recommended values $(60 \%$ and $40 \%$, respectively), while ratios in its meat are slightly lower [57]. Previous reports demonstrated that other edible insects, namely Tenebrio molitor, Acheta domesticus, and Locusta migratoria, contain seven essential amino acids, but the balance of EAAs is not as good as in C. bilineata tsingtauica. For example, the EAA/NEAA ratios in T. molitor, A. domesticus, and L. migratoria are only 57.32\%, 55.04\%, and 56.09\%, respectively [58].

Minerals are essential micronutrients for animals and humans [59]. In this study, we measured the concentrations of eight minerals in $C$. bilineata tsingtauica and found that $\mathrm{Zn}$ is the highest in C. bilineata tsingtauica meat and Fe is highest in the epidermis. The recommended human intake of Fe and $\mathrm{Zn}$ is $15 \mathrm{mg} /$ day [60,61], and $\mathrm{Zn}$ deficiency is highly prevalent in children and women in developing countries [62,63]. Additionally, phytic acid acts as an anti-nutrient by binding to $\mathrm{Fe}$ and $\mathrm{Zn}$; this prevents the absorption of minerals in the gastrointestinal tract and decreases their bioavailability [64,65]. Phytic acid is present in numerous edible insect species (see Table 7 in [41]), and the PA/Zn and PA/Fe molar ratios of cereal and legumes are important considerations [66]. This study showed that the $\mathrm{PA} / \mathrm{Zn}$ and PA/Fe ratios in C. bilineata tsingtauica are lower than in G. max, indicating that $\mathrm{Zn}, \mathrm{Fe}$, and bioavailability are higher in C. bilineata tsingtauica than in G. max. Therefore, the consumption of $C$. bilineata tsingtauica can alleviate the Fe and $\mathrm{Zn}$ deficiency caused by cereal- and bean-based diets in some areas [64,67], and can be used as a zinc supplement to reduce childhood morbidity and mortality in developing countries [68,69].

In conclusion, this study evaluated the nutritional value of C. bilineata tsingtauica, a rich source of protein and minerals. PA is present in C. bilineata tsingtauica and C. atrata, but the ratios showed that the bioavailability of minerals in these insects is superior to G. max. It is important to note that nutrition is distributed throughout the insect body, including the fat body in the abdomen and beneath the epidermis [70,71]. Based on our results, we advocate that the traditional way of eating $C$. bilineata tsingtauica in Lianyungang should be changed, and recommend the consumption of the entire larvae as is common in Xuzhou and Shandong. Future research should address the determination of toxic and beneficial substances in C. bilineata tsingtauica, and breeding technologies need to be improved to meet consumer demands for C. bilineata tsingtauica products.

Author Contributions: Conceptualization, Y.S. and M.-X.L.; methodology, M.-X.L.; software, L.-Q.J.; validation, M.Z., L.Q. and L.-Q.J.; formal analysis, M.-X.L.; investigation, M.Z.; resources, H.-J.L.; data curation, Y.S.; writing — original draft preparation, Y.S. and M.-X.L.; writing—review and editing, Y.S., M.-X.L., H.-J.L. and Y.-Z.D.; visualization, M.Z.; supervision, Y.-Z.D.; project administration, M.-X.L.; funding acquisition, H.-J.L. All authors have read and agreed to the published version of the manuscript.

Funding: This research was funded by Jiangsu Agricultural Science and Technology Innovation Fund (CX (19) 2036).

Institutional Review Board Statement: Not applicable.

Informed Consent Statement: Not applicable.

Data Availability Statement: Not applicable.

Acknowledgments: We thank the Key Laboratory of Crop Genetics and Physiology of Jiangsu Province, College of Agriculture, Yangzhou University for their assistance with sample determination. We also sincerely thank Carol L. Bender and the anonymous reviewers for their English editing and helpful comments regarding the manuscript.

Conflicts of Interest: The authors declare no conflict of interest.

\section{References}

1. Singh, V.K.; Ellur, R.K.; Singh, A.K.; Nagarajan, M.; Singh, B.D.; Singh, N.K. Effect of $q$ GN4.1 QTL for grain number per panicle in genetic backgrounds of twelve different mega varieties of rice. Rice 2018, 11, 8. [CrossRef] 
2. Meyer-Rochow, V.B. Can insects help to ease the problem of world food shortage? Search 1975, 6, 261-262.

3. Hong, J.; Han, T.; Kim, Y.Y. Mealworm (Tenebrio molitor Larvae) as an alternative protein source for monogastric animal: A review. Animals 2020, 10, 2068. [CrossRef]

4. Huis, V.A.; Itterbeeck, J.V.; Klunder, H.; Mertens, E.; Vantomme, P. Edible Insects: Future Prospects for Food and Feed Security; FAO: Rome, Italy, 2013; Volume 171, pp. 1-201.

5. Kim, S.Y.; Kwak, K.-W.; Park, E.-S.; Yoon, H.J.; Kim, Y.-S.; Park, K.; Kim, E.; Kim, S.-D. Evaluation of subchronic oral dose toxicity of freeze-dried skimmed powder of Zophobas atratus Larvae (frpfdZAL) in Rats. Foods 2020, 9, 995. [CrossRef] [PubMed]

6. Vilcinskas, A.; Schwabe, M.; Brinkrolf, K.; Plarre, R.; Wielsch, N.; Vogel, H. Larvae of the clothing moth Tineola bisselliella maintain gut bacteria that secrete enzyme cocktails to facilitate the digestion of keratin. Microorganisms 2020, 8, 1415. [CrossRef]

7. Nowak, V.; Persijn, D.; Rittenschober, D.; Charrondiere, U.R. Review of food composition data for edible insects. Food Chem. 2016, 193, 39-46. [CrossRef] [PubMed]

8. Nakane, W.; Nakamura, H.; Nakazato, T.; Kaminaga, N.; Nakano, M.; Sakamoto, T.; Nishiko, M.; Bono, H.; Ogiwara, I.; Kitano, Y.; et al. Construction of TUATinsecta database that integrated plant and insect database for screening phytophagous insect metabolic products with medicinal potential. Sci. Rep. 2020, 10, 1-11. [CrossRef]

9. Elhassan, M.; Wendin, K.; Olsson, V.; Langton, M. Quality aspects of insects as food-Nutritional, sensory, and related concepts. Foods 2019, 8, 95. [CrossRef]

10. Huis, A.V. Potential of insects as food and feed in assuring food security. Annu. Rev. Entomol. 2013, 58, 563-583. [CrossRef]

11. Lyke, M.M.; Di Fiore, A.; Fierer, N.; Madden, A.A.; Lambert, J.E. Metagenomic analyses reveal previously unrecognized variation in the diets of sympatric Old World monkey species. PLoS ONE 2019, 14, e0218245. [CrossRef]

12. McGrew, W.C. The 'other faunivory' revisited: Insectivory in human and non-human primates and the evolution of human diet. J. Hum. Evol. 2014, 71, 4-11. [CrossRef] [PubMed]

13. Rothman, J.M.; Raubenheimer, D.; Bryer, M.A.; Takahashi, M.; Gilbert, C. Nutritional contributions of insects to primate diets: Implications for primate evolution. J. Hum. Evol. 2014, 71, 59-69. [CrossRef] [PubMed]

14. Claudia, C.; Miranda, M.; John, B. Potential of extracted Locusta Migratoria protein fractions as value-added ingredients. Insects 2018, 9, 20 .

15. Wendin, K.; Mårtensson, L.; Djerf, H.; Langton, M. Product quality during the storage of foods with insects as an ingredient: Impact of particle size, antioxidant, oil content and salt content. Foods 2020, 9, 791. [CrossRef]

16. Zielińska, E.; Baraniak, B.; Karaś, M.; Rybczyńska-Tkaczyk, K.; Jakubczyk, A. Selected species of edible insects as a source of nutrient composition. Food Res. Int. 2015, 77, 460-466. [CrossRef]

17. Zielińska, E.; Baraniak, B.; Karaś, M. Antioxidant and anti-inflammatory activities of hydrolysates and peptide fractions obtained by enzymatic hydrolysis of selected heat-treated edible insects. Nutrients 2017, 9, 970. [CrossRef]

18. Gasco, L.; Biasato, I.; Dabbou, S.; Schiavone, A.; Gai, F. Animals fed insect-based diets: State-of-the-art on digestibility, performance and product quality. Animals 2019, 9, 170. [CrossRef] [PubMed]

19. Ghosh, S.; Jung, C. Nutritional value of bee-collected pollens of hardy kiwi, Actinidia arguta (Actinidiaceae) and oak, Quercus sp. (Fagaceae). J. Asia-Pac. Entomol. 2017, 20, 245-251. [CrossRef]

20. Chakravorty, J.; Ghosh, S.; Jung, C.; Meyer-Rochow, V.B. Nutritional composition of Chondacris rosea and brachytrupes orientalis: Two common insects used as food by tribes of arunachal pradesh, india. J. Asia-Pac. Entomol. 2014, 17, 407-415. [CrossRef]

21. Terova, G.; Gini, E.; Gasco, L.; Moroni, F.; Antonini, M.; Rimoldi, S. Effects of full replacement of dietary fishmeal with insect meal from Tenebrio molitor on rainbow trout gut and skin microbiota. J. Anim. Sci. Biotechnol. 2021, 12, 1-14. [CrossRef]

22. Rumpold, B.A.; Schlüter, O.K. Nutritional composition and safety aspects of edible insects. Mol. Nutr. Food Res. 2013, 57, 802-823. [CrossRef]

23. Fontaneto, D.; Tommaseo-Ponzetta, M.; Galli, C.; Risé, P.; Glew, R.H.; Paoletti, M.G. Differences in fatty acid composition between aquatic and terrestrial insects used as food in human nutrition. Ecol. Food Nutr. 2011, 50, 351-367. [CrossRef]

24. Feng, Y.; Chen, X.-M.; Zhao, M.; He, Z.; Sun, L.; Wang, C.-Y.; Ding, W.-F. Edible insects in China: Utilization and prospects. Insect Sci. 2018, 25, 184-198. [CrossRef]

25. Feng, Y.Y.; Ma, G.C.; Jin, Q.A.; Lü, B.Q.; Peng, Z.Q.; Jin, T.; Wen, H.B. Effect of temperature on developmental duration and feeding amount of Clanis bilineata tsingtauica. Chin. J. Trop. Crop. 2014, 35, 2442-2444.

26. Guo, M.M.; Li, X.F.; Deng, P.; Li, D.W.; Li, J.L.; Fan, J.W.; Chen, F. Diapause termination and post-diapause of overwintering Clanis bilineata tsingtauica larvae. Chin. J. Appl. Entomol. 2021, 58, 966-972.

27. Tian, H.; Zhang, Y.M. Advances of integrated utilization on resource insect Clanis bilineata tsingtauica. Guizhou Agric. Sci. 2009, 37, 111-113.

28. Guo, M.M.; Liao, H.J.; Deng, P.; Li, D.W.; Li, J.L.; Zhang, J.Q.; Fan, J.W.; Chen, F. Effects of soybean varieties (lines) and planting density on survival and development of Clanis bilineata tsingtauica Mell larvae. J. Environ. Entomol. 2020, 42, 1401-1408.

29. Tian, H.; Zhang, Y.M. The nutritional components analysis and evaluation of Clanis bilineata tsingtauica Mell. Acta Nutr. Sin. 2012, 34, 289-291.

30. Doumani, N.; Severin, I.; Dahbi, L.; Bou-Maroun, E.; Tueni, M.; Sok, N.; Chagnon, M.-C.; Maalouly, J.; Cayot, P. Lemon juice, sesame paste, and autoclaving influence iron bioavailability of hummus: Assessment by an in vitro digestion/Caco-2 cell model. Foods 2020, 9, 474. [CrossRef] [PubMed] 
31. Jobarteh, M.L.; McArdle, H.J.; Holtrop, G.; Sise, E.A.; Prentice, A.M.; Moore, S.E. mRNA levels of placental iron and zinc transporter genes are upregulated in Gambian women with low iron and zinc status. J. Nutr. 2017, 147, 1401-1409. [CrossRef]

32. Rebholz, C.M.; Lichtenstein, A.H.; Zheng, Z.; Appel, L.J.; Coresh, J. Serum untargeted metabolomic profile of the Dietary Approaches to Stop Hypertension (DASH) dietary pattern. Am. J. Clin. Nutr. 2018, 108, 243-255. [CrossRef]

33. Clements, R.S.; Darnell, B. Myo-inositol content of common foods: Development of a high-myo-inositol diet. Am. J. Clin. Nutr. 1980, 33, 1954-1967. [CrossRef] [PubMed]

34. Steadman, K.J.; Burgoon, M.S.; Schuster, R.L.; Lewis, B.A.; Edwardson, S.E.; Obendorf, R.L. Fagopyritols, D-chiro-inositol, and other soluble carbohydrates in buckwheat seed milling fractions. J. Agric. Food Chem. 2000, 48, 2843-2847. [CrossRef] [PubMed]

35. Silva, E.O.; Bracarense, A.P.F.; Bracarense, A.P. Phytic acid: From antinutritional to multiple protection factor of organic systems. J. Food Sci. 2016, 81, R1357-R1362. [CrossRef]

36. Joseph, L. D-chiro-inositol-Its functional role in insulin action and its deficit in insulin resistance. Int. J. Exp. Diabetes Res. 2002, $3,47-60$.

37. Gupta, S.; Habeych, E.; Scheers, N.; Merinat, S.; Rey, B.; Galaffu, N.; Sandberg, A.-S. The development of a novel ferric phytate compound for iron fortification of bouillons (part I). Sci. Rep. 2020, 10, 5340. [CrossRef]

38. Sandberg, A.-S.; Andersson, H. The effect of dietary phytase on the digestion of phytate in the stomach and small intestine of humans. J. Nutr. 1988, 118, 469-473. [CrossRef]

39. Hurrell, R.F. Phytic acid degradation as a means of improving iron absorption. Int. J. Vitam. Nutr. Res. 2004, 74, 445-452. [CrossRef] [PubMed]

40. Brune, M.; Rossander-Hultén, L.; Hallberg, L.; Gleerup, A.; Sandberg, A.-S. Iron absorption from bread in humans: Inhibiting effects of cereal fiber, phytate and inositol phosphates with different numbers of phosphate groups. J. Nutr. 1992, 122, 442-449. [CrossRef]

41. Meyer-Rochow, V.; Gahukar, R.; Ghosh, S.; Jung, C. Chemical composition, nutrient quality and acceptability of edible insects are affected by species, developmental stage, gender, diet, and processing method. Foods 2021, 10, 1036. [CrossRef]

42. Chakravorty, J.; Ghosh, S.; Megu, K.; Jung, C.; Meyer-Rochow, V.B. Nutritional and anti-nutritional composition of Oecophylla smaragdina (Hymenoptera: Formicidae) and Odontotermes sp. (Isoptera: Termitidae): Two preferred edible insects of Arunachal Pradesh, India. J. Asia-Pac. Entomol. 2016, 19, 711-720. [CrossRef]

43. Liu, X.; Chen, X.; Wang, H.; Yang, Q.; ur Rehman, K.; Li, W.; Cai, M.; Li, Q.; Mazza, L.; Zhang, J.; et al. Dynamic changes of nutrient composition throughout the entire life cycle of black soldier fly. PLoS ONE 2017, 12, e0182601. [CrossRef] [PubMed]

44. Zhou, X.; Zhou, J.; Wang, Y.; Peng, B.; Zhu, J.; Yang, L.; Wang, Y. Elevated tropospheric ozone increased grain protein and amino acid content of a hybrid rice without manipulation by planting density. J. Sci. Food Agric. 2014, 95, 72-78. [CrossRef] [PubMed]

45. Ju, Z.; Hettiarachchy, N.; Rath, N. Extraction, denaturation and hydrophobic properties of rice flour proteins. J. Food Sci. 2001, 66, 229-232. [CrossRef]

46. Toshio, S.; Kunisuke, T.; Zenzaburo, K. Improved extraction of rice prolamin. Agric. Biol. Chem. 1986, 50, $2409-2411$.

47. Jing, L.; Chen, C.; Hu, S.; Dong, S.; Pan, Y.; Wang, Y.; Lai, S.; Wang, Y.; Yang, L. Effects of elevated atmosphere $\mathrm{CO}_{2}$ and temperature on the morphology, structure and thermal properties of starch granules and their relationship to cooked rice quality. Food Hydrocoll. 2021, 112, 106360. [CrossRef]

48. Qiao, T.S.; Tang, H.C.; Liu, J.X.; Li, L. Analysis of nutritional components and evaluation of protein quality of Oxya chinensis. Chin. Bull. Entomol. 1992, 29, 113-117.

49. Huis, A.V. Prospects of insects as food and feed. Org. Agric. 2021, 11, 301-308. [CrossRef]

50. Khampakool, A.; Soisungwan, S.; You, S.G.; Park, S.H. Infrared assisted freeze-drying (IRAFD) to produce shelf-stable insect food from Protaetia brevitarsis (white-spotted flower chafer) larva. Food Sci. Anim. Resour. 2020, 40, 813-830. [CrossRef]

51. Mi, Y.C.; Gwon, E.Y.; Hwang, J.S.; Goo, T.W.; Yun, E.Y. Analysis of general composition and harmful material of Protaetia brevitarsis. J. Life Sci. 2013, 23, 664-668.

52. Melis, R.; Braca, A.; Mulas, G.; Sanna, R.; Spada, S.; Serra, G.; Leonarda, F.M.; Roggio, T.; Uzzau, S.; Anedda, R. Effect of freezing and drying processes on the molecular traits of edible yellow mealworm. Innov. Food Sci. Emerg. Technol. 2018, 48, 138-149. [CrossRef]

53. Kwon, Y.J.; Lee, H.S.; Park, J.Y.; Lee, J.W. Associating intake proportion of carbohydrate, fat, and protein with all-cause mortality in Korean adults. Nutrients 2020, 12, 3208. [CrossRef]

54. Carreiro, A.L.; Dhillon, J.; Gordon, S.; Higgins, K.A.; Jacobs, A.G.; McArthur, B.M.; Redan, B.W.; Rivera, R.L.; Schmidt, L.R.; Mattes, R.D. The macronutrients, appetite, and energy intake. Annu. Rev. Nutr. 2016, 36, 73-103. [CrossRef] [PubMed]

55. Kim, T.K.; Yong, H.I.; Chang, H.J.; Han, S.G.; Kim, Y.B.; Paik, H.D.; Choi, Y.S. Technical functional properties of water- and salt-soluble proteins extracted from edible insects. Food Sci. Anim. Resour. 2019, 39, 643-654. [CrossRef]

56. Pali-Scholl, I.; Meinlschmidt, P.; Larenas-Linnemann, D.; Purschke, B.; Hofstetter, G.; Rodriguez-Monroy, F.A.; Einhorm, L.; Mothes-Luksch, N.; Jensen-Jarolim, E.; Jager, H. Edible insects: Cross-recognition of IgE from crustacean and house dust mite allergic patients, and reduction of allergenicity by food processing. World Allergy Organ. J. 2019, 12, 100006. [CrossRef]

57. Li, Y.C.; Li, K.; Dai, R.H. Analysis and evaluation of nutrition of Opisthoplata orientalis Buron. J. Environ. Entomol. 2013, 35, $466-472$.

58. Boulos, S.; Tnnler, A.; Nystrm, L. Nitrogen-to-protein conversion factors for edible insects on the Swiss market: T. molitor, A. domesticus, and L. migratoria. Front. Nutr. 2020, 7, 89. [CrossRef] 
59. Liu, J.; Huang, L.; Li, T.X.; Liu, Y.X.; Yan, Z.H.; Tang, G.; Zheng, Y.L.; Liu, D.C.; Wu, B.H. Genome-wide association study for grain micronutrient concentrations in wheat advanced lines derived from wild emmer. Front. Plant Sci. 2021, 12, 651283. [CrossRef]

60. Calayugan, M.; Formantes, A.K.; Amparado, A.; Descalsota-Empleo, G.I.; Nha, C.T.; Inabangan-Asilo, M.A.; Swe, Z.M.; Hernandez, J.E.; Borromeo, T.H.; Lalusin, A.G.; et al. Genetic analysis of agronomic traits and grain iron and zinc concentrations in a doubled haploid population of rice (Oryza sativa L.). Sci. Rep. 2020, 10, 2283. [CrossRef]

61. Welch, R.M.; Graham, R.D. Breeding for micronutrients in staple food crops from a human nutrition perspective. J. Exp. Bot. 2004, 55, 353-364. [CrossRef]

62. Sandstead, H.H. Is zinc deficiency a public problem? Nutrition 1995, 11, 87-92.

63. Baqui, A.H.; Black, R.E.; Arifeen, S.E.; Yunus, M.; Chakraborty, J.; Ahmed, S.; Vaughan, J.P. Effect of zinc supplementation started during diarrhoea on morbidity and mortality in Bangladeshi children: Community randomised trial. BMJ 2002, 325, 1059-1062. [CrossRef]

64. Caproni, L.; Raggi, L.; Talsma, E.F.; Wenzl, P.; Negri, V. European landrace diversity for common bean biofortification: A genome-wide association study. Sci. Rep. 2020, 10, 19775. [CrossRef]

65. Luzak, A.; Heier, M.; Thorand, B.; Laxy, M.; Nowak, D.; Peters, A.; Schulz, H. Physical activity levels, duration pattern and adherence to WHO recommendations in german adults. PLoS ONE 2017, 12, e0172503. [CrossRef]

66. Lowe, N.M.; Khan, M.J.; Broadley, M.R.; Zia, M.H.; Mcardle, H.J.; Joy, E.J.; Ohly, H.; Shahzad, B.; Ullah, U.; Kabana, G.; et al. Examining the effectiveness of consuming flour made from agronomically biofortified wheat (Zincol-2016/NR-421) for improving $\mathrm{Zn}$ status in women in a low-resource setting in Pakistan: Study protocol for a randomised, double-blind, controlled cross-over trial (BiZiFED). BMJ Open 2018, 8, e021364.

67. Petry, N.; Boy, E.; Wirth, J.P.; Hurrell, R.F. Review: The potential of the common bean (Phaseolus vulgaris) as a vehicle for iron biofortification. Nutrients 2015, 7, 1144-1173. [CrossRef] [PubMed]

68. Walker, C.F.; Black, R.E. Zinc and the risk for infectious disease. Annu. Rev. Nutr. 2004, 24, 255-275. [CrossRef] [PubMed]

69. Cole, C.R.; Grant, F.K.; Dawn, S.; Smith, J.L.; Anne, J.; Northrop-Clewes, C.A.; Calawell, K.L.; Pfeiffer, C.M.; Ziegler, T.R. Zinc and iron deficiency and their interrelations in low-income African American and Hispanic children in Atlanta. Am. J. Clin. Nutr. 2010, 91, 1027-1034. [CrossRef] [PubMed]

70. Li, L.F.; Gao, X.; Lan, M.X.; Yuan, Y.; Guo, Z.J.; Tang, P.; Li, M.Y.; Liao, X.B.; Zhu, J.Y.; Li, Z.Y.; et al. De novo transcriptome analysis and identification of genes associated with immunity, detoxification and energy metabolism from the fat body of the tephritid gall fly, Procecidochares utilis. PLoS ONE 2019, 14, e226039. [CrossRef] [PubMed]

71. Arrese, E.L.; Soulages, J.L. Insect fat body: Energy, metabolism, and regulation. Annu. Rev. Entomol. 2010, 55, 207-225. [CrossRef] 